Nig. J. Biotech. Vol. 37(1): 63-77 (June 2020)

ISSN: 01891731

Available online at

http://www.ajol.info/index.php/njb/index

and www.biotechsocietynigeria.org

DOI: https://dx.doi.org/10.4314/njb.v37i1.7

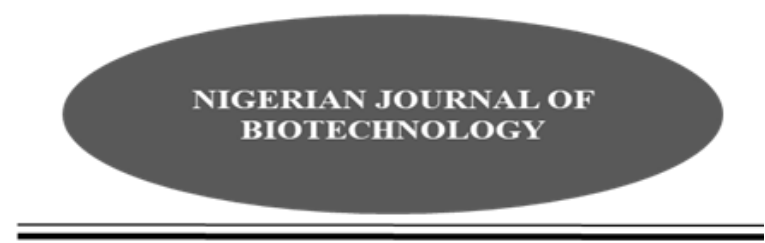

\title{
IL4, IL13, GSTM1 and T1 variants and susceptibility to Schistosomiasis and associated bladder pathologies in Eggua, Nigeria
}

\author{
1*Onile, O. S., ${ }^{2}$ Awobode H. O., ${ }^{3}$ Agunloye A. M., ${ }^{4}$ Marquez-Duenas C., \\ ${ }^{4}$ Manning Cela R. G. and ${ }^{5 *}$ Anumudu C. I.
}

\begin{abstract}
${ }^{1}$ Biotechnology Programme, Department of Biological Sciences, Elizade University, Ilara-Mokin, Nigeria; ${ }^{2}$ Parasitology Unit, Department of Zoology, University of Ibadan, Ibadan, Nigeria; ${ }^{3}$ Department of Radiology, University College Hospital, University of Ibadan, Nigeria, ${ }^{4}$ Department of Molecular Biomedicine, Centro de Investigación y de Estudios Avanzados del Instituto Politécnico Nacional, Mexico D.F.; ${ }^{5}$ Cellular Parasitology Programme, Department of Zoology, University of Ibadan, Ibadan, Nigeria.
\end{abstract}

\begin{abstract}
Failure of the human host to elicit adequate immune responses to the adult Schistosoma haematobium worm and continuous strong inflammatory responses to the eggs have been the main causes of bladder pathology in chronic Schistosomiasis. Identification of susceptibility biomarkers for schistosomiasis- associated bladder pathology is necessary in order to detect genetic factors responsible for the infection and spread of the disease. The aim of this study was to identify candidate-biomarkers for susceptibility to schistosomiasis and its associated pathologies. A total of 371 adult participants, comprising 130 males and 241 females from Eggua community, Ogun State, Nigeria, were randomly recruited into a cross sectional study from August 2012 to May 2014. They were screened for S. haematobium ova and bladder pathologies by microscopy and ultrasonography, respectively. Human host susceptibility to schistosomiasis and its associated bladder pathologies were determined by PCR genotyping of Interleukin (IL4 and IL13) genes, and glutathione-S-transferase (GSTT1 and GSTM1) genes. The overall prevalence of $S$. haematobium in the population was $29.3 \%$ $(108 / 369)$. Bladder pathologies were observed in $32.3 \%(117 / 362)$ of the population. Polymorphisms in $I L$ 4-590 and $I L$ 13-1055 were observed in $24.1 \%$ and $9.3 \%$ schistosomiasis cases, respectively. The IL 13-1055 polymorphism did not indicate susceptibility to schistosomiasis in males (OR 0.7, 95\% CI 0.3-2.1) but a slight risk was found in females (OR 1.1, 95\% CI 0.7-1.7). Participants with GSTM1 and GSTT1 polymorphisms expressed elevated risks of bladder pathologies $(O R=4.3,95 \%$ CI $2.0-9.2$ and $O R=4.2,95 \%$ CI $1.5-12.0$, respectively), with the pathology and schistosomiasis group having more GST polymorphisms than bladder pathologies.
\end{abstract}

Keywords: Polymorphisms, Cytokines, GST, schistosomiasis and pathologies

*Corresponding Author's Address: Email: cianumudu@yahoo.com;

olugbenga.onile@elizadeuniversity.edu.ng, Phone Number: +2348023590478; +2348133109389

\section{Introduction}

Not less than 700 million persons are globally estimated to be infected with schistosomiasis and at least 206.4 million people required preventive treatment in 2016 (Yassir et. al.,
2017; WHO, 2018). Nigeria is one of the most severely affected countries in Africa, with 29 million cases as at 2010 (Adenowo et. al., 2015). Indeed, a recent meta-analysis of schistosomiasis prevalence studies in Nigeria shows that the prevalence in Nigeria varied 
from $2-82.5 \%$ with a pooled prevalence of $34.7 \%$ (Abdulkadir et. al., 2017). Chronic morbidity during urinary schistosomiasis develops as a result of schistosome eggs that lodge in the bladder causing extensive tissue damage (Wilson et. al., 2007). The response to egg deposition could lead to calcification of the urinary bladder, infection, stone formation and mucosal proliferation (Zaghloul, 2012). Chronic infection with Schistosoma haematobium has been reported as a possible risk factor in the aetiology of bladder cancer (European Association of Urology, 2016; Onile et. al., 2016).

The intensity of schistosomiasis is reportedly influenced by a Schistosoma mansoni 1 (SM1) gene that is mapped to a region of chromosome 5 in the 5q31-q33 that codes for proteins that are associated with regulation of the Th2 response such as cytokines like Interleukin (IL)3, IL-4, IL-5, IL-9, and IL-13 and Immunoglobulin (Ig) E (Dessein et. al., 2001; Gatlin et. al., 2009; Mbanefo et. al., 2014). Gatlin et. al., (2009) in a univariate analysis reported a significant correlation between resistance to reinfection with Schistosoma mansoni and the heterozygous (C/T) IL-13 1055 genotype, any $T$ allele in the Interferon (IFN)-c +874 genotype, and the heterozygous $(\mathrm{C} / \mathrm{T})$ in the IL-4 -590 genotype. Analysis of $S$. haematobium infection in Mali revealed that polymorphisms in the IL13 gene promoter at -1055 and -591 were associated with the rate of Schistosoma infection. The IL-13 alleles $-1055 \mathrm{C}$ and $-591 \mathrm{~A}$ were preferentially transmitted to children with $\quad 10 \%$ highest infection rate, whereas $-1055 \mathrm{~T}$ was associated with the lowest infection levels (Kouriba et. al., 2005).

It is thought that schistosomes redirect the early cell-mediated immunity in infection to cytokines that would favour establishment of the infection. $S$. haematobium infectionassociated bladder damage is closely linked to immune reaction to the parasite deposited egg in the bladder which eventually induces chronic inflammation- related granulomatous injury. We propose that infected and re-infected persons are genetically directed to produce inappropriate cytokine responses that lead to the establishment of chronic infections.

Decrease in the activity of the carcinogenmetabolizing enzyme glutathione-S-transferase (GST) in human bladder cancer tissues have been associated with $S$. haematobium infection (Sheweita et. al., 2004). Somali et. al., (2003) and Yajie et. al., (2016) found that deficiencies in the GSTT1 gene confer an increased risk of bladder cancer. The inhibition of GST activity may enhance the effect of many environmental carcinogens such as $\mathrm{N}$-nitrosamines, thereby reducing the capacity of detoxifying many endogenous compounds in the bladder (Yajie et. al., 2016).

In Nigeria, most studies have focused on the epidemiology of $S$. haematobium infection (Adenowo et. al., 2015 and Abdulkadir et. al., 2017), with limited information about the morbidity resulting from urinary schistosomiasis in adults (Nmorsi et. al., 2007; Ekwunife et. al., 2009; Onile et. al., 2016) while information on schistosomiasis susceptibility and resistance factors are lacking. This study was aimed at genotyping polymorphisms in Interleukin (IL-4 and $I L-13$ ) and GST ( $M 1$ and $T 1$ ) genes and determining their association with genetic susceptibility to schistosomiasis and its pathologies.

\section{Materials and Methods}

The study design, area, methods and participants have been described previously (Onile et. al., 2016; Anumudu et. al., 2019). Briefly, a cross- sectional study was carried out from August 2012 to May 2014 in Eggua (Figure 1), a rural agrarian community where $S$. haematobium infections are prevalent. Children and participants with human immunodeficiency virus (HIV) were excluded from the study because the main objective was to determine the effect of chronic urinary schistosomiasis on the health of the adults within the community. 

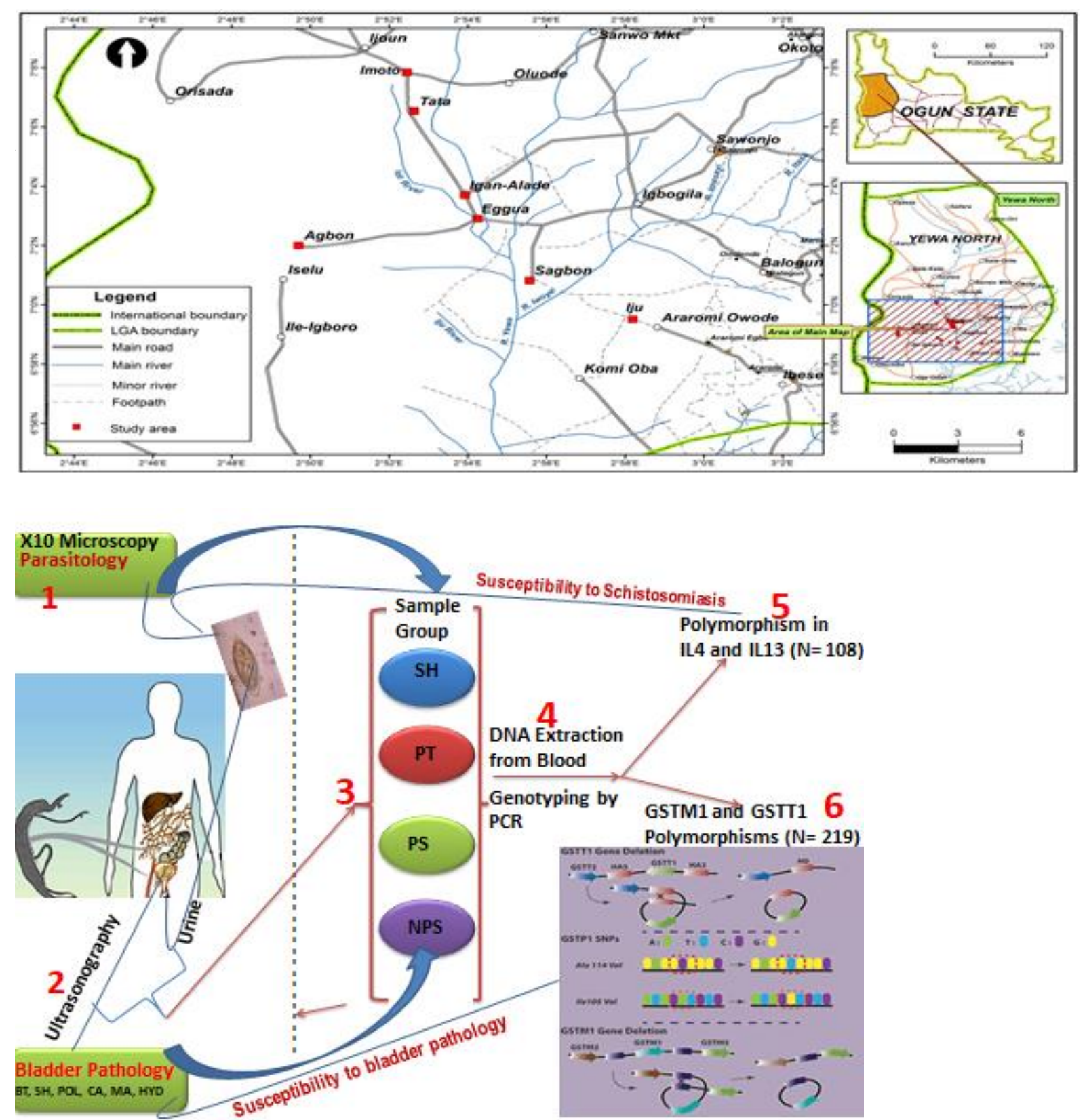

Figure 2: Polymorphisms in IL4, IL13, GSTM1 and T1 in susceptibility to schistosomiasis and associated bladder pathologies. Abbreviations: SH- S. haematobium infected groups, PT- Bladder Pathology group, PS- group with combination of pathology and $S$. haematobium infection and NPS- No pathology and schistosomiasis (Control). GSTs- Glutathione-S-transferase, IL- cytokine Interleukin

\section{3.}

\section{Parasitology}

Study volunteers provided blood $(2 \mathrm{~mL})$ by venipuncture and urine (for egg count) specimens. The urine samples were collected between 10:00am and 2:00pm for maximum egg yield and were processed for parasitological examination and egg count (as previously described (Onile et. al., 2017; Adebayo et. al., 2017; Olayinka et. al., 2020). The urine sediment (obtained by centrifuging $10 \mathrm{ml}$ of sample at $5000 \mathrm{rpm}$ for 5 minutes) was examined microscopically to identify Schistosoma haematobium ova characterised by the presence of a terminal spine. The eggs were counted and the intensity of infection classified as light if $\leq 50$ eggs $/ 10 \mathrm{~mL}$ of urine and heavy if $>50$ egg/10 $\mathrm{mL}$ urine were present 
(Nmorsi et. al., 2007; Onile et. al., 2016). In addition to microscopy, detection of macro and microhaematuria (urinalysis) for schistosomiasis was also done as described in Onile et. al., (2017)

\section{$4 . \quad \quad$ Ultrasound and Pathology}

A blind ultrasound examination was carried out by a radiologist for each participant in the study and classification of bladder pathologies was as previously described (Onile et. al., 2016).

\section{5. \\ DNA Extraction and} Purification

DNA was purified from the blood samples using Thermos Scientific GeneJET Whole Blood Genomic DNA purification kit (Lithuania), following the manufacturer's instructions. DNA concentration was measured by spectrophotometry. Aliquots $(10 \mu \mathrm{L})$ of all samples was taken and subsequently adjusted to provide standard stock solutions of $20 \mathrm{ng} / \mu \mathrm{L}$. The $A 280 / A 260$ ratio was estimated to provide an indication of the quality of the sample. Only samples that provided a yield of $>20 \mathrm{ng} / \mu \mathrm{L}$ and $A 280 / A 260$ ratio $>1.8$ and $<1.95$ were included for genotyping analysis.

\section{Genotyping for IL 4 and IL 13 Genes}

PCR for IL-13 and IL-4 Single nucleotide polymorhisms (SNPs) was performed for 108 samples from the participants that tested positive for urinary schistosomiasis by microscopy, using modifications from the original methods (references in Table 1), which enhanced optimal amplification.

PCR for IL-13 -1055 C/T was conducted in a 25 $\mu \mathrm{l}$ reaction mixture containing $100 \mathrm{ng}$ DNA.
Initial denaturation was performed at $95^{\circ} \mathrm{C}$ for 3 min followed by 30 cycles of PCR with the following conditions: $95^{\circ} \mathrm{C}$ for $30 \mathrm{sec}, 62^{\circ} \mathrm{C}$ for $30 \mathrm{sec}$ for annealing, $72^{\circ} \mathrm{C}$ for $1 \mathrm{~min}$ for amplification, and a final extension at $72^{\circ} \mathrm{C}$ for $3 \mathrm{~min}$. This was done using the Hot Start Taq 2X Master Mix (M0496L, BioLabs, New England).

PCR for IL-13 -591 A/G was conducted in a 25 $\mu \mathrm{L}$ reaction mixture containing $100 \mathrm{ng}$ DNA and was done using the Hot Start Taq 2X Master Mix (M0496L, BioLabs, New England). Initial denaturation was performed at $94^{\circ} \mathrm{C}$ for 5 min followed by 30 cycles of PCR with the following conditions: $94^{\circ} \mathrm{C}$ for $1 \mathrm{~min}, 61^{\circ} \mathrm{C}$ for $45 \mathrm{sec}$ for annealing, $72^{\circ} \mathrm{C}$ for $45 \mathrm{sec}$ for amplification, and a final extension at $72^{\circ} \mathrm{C}$ for $3 \mathrm{~min}$.

PCR for IL-13 +130 G/A was conducted in a 25 $\mu \mathrm{L}$ reaction mixture containing $100 \mathrm{ng}$ DNA and the PCR reaction was done using the Hot Start Taq 2X Master Mix (M0496L, BioLabs, New England). Initial denaturation was performed at $94^{\circ} \mathrm{C}$ for 5 min followed by 34 cycles of PCR with the following conditions: $94^{\circ} \mathrm{C}$ for $1 \mathrm{~min}, 60^{\circ} \mathrm{C}$ for $45 \mathrm{sec}$ for annealing, $72^{\circ} \mathrm{C}$ for $45 \mathrm{sec}$ for amplification, and a final extension at $72^{\circ} \mathrm{C}$ for 3 min.

PCR for IL-4 -590 C/T was conducted in a $25 \mu \mathrm{L}$ reaction mixture containing $100 \mathrm{ng}$ DNA, using the Hot Start Taq 2X PCR Master Mix (M0496L, BioLabs, New England). Initial denaturation was performed at $95^{\circ} \mathrm{C}$ for 5 min followed by 30 cycles of PCR with the following conditions: $94^{\circ} \mathrm{C}$ for $30 \mathrm{sec}, 59^{\circ} \mathrm{C}$ for $30 \mathrm{sec}$ for annealing, $72^{\circ} \mathrm{C}$ for $30 \mathrm{sec}$ for amplification, and a final extension at $72^{\circ} \mathrm{C}$ for 3 min. 21 Purified PCR amplicons were further sent for sequencing (Fig. 3). 


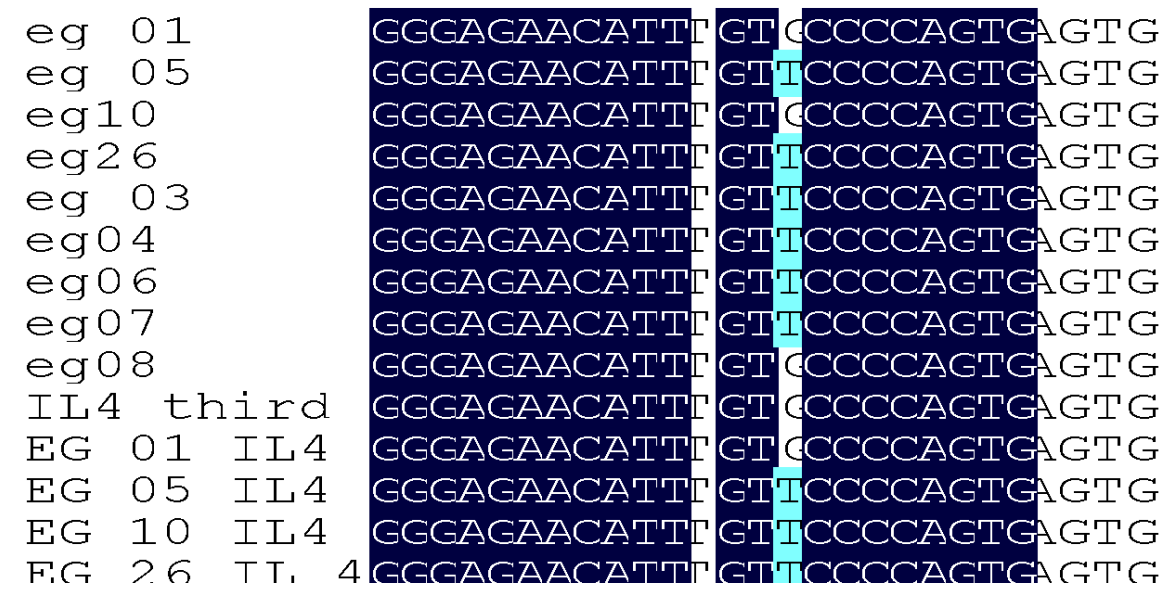

Figure 3: Identifying polymorphisms in IL4 509 T/C sequence, sense strand from Eggua

6.

GSTM1 and GSTT1

\section{Genotyping}

A total of 219 samples were genotyped for GST polymorphisms; these included 118 urinary tract pathology and 101 control cases. The control cases were randomly selected from among participants. The genotypes GSTM1-null and GSTT1-null, produced no GSTM1 and GSTT1 protein and consequently completely lack GSTM1 and GSTT1 enzymatic activity (Matic et. al., 2016).

1.

Genotyping for GSTM1

\section{Polymorphism}

This reaction was used to distinguish between GSTM1-active and GSTM1-null individuals. Two primers ( $G 1$ and $G 2$ ) were used to amplify GSTM1 complementary DNA sequences (Brockmoller et. al., 2000). The G1 and G2 amplified a 500- base pair (bp) product specific for the GSTM1 gene. The presence of a GSTM1-null polymorphism was concluded from the absence of the specific 500-base pair fragment. $5 \mu \mathrm{L}$ DNA was amplified in a final volume of $25 \mu \mathrm{L}$ amplification reaction of 30 cycles, using the Hot Start Taq 2X Master Mix (M0496L, BioLabs, New England) according to the manufacturer's instructions.

2.

Polymorphism

Genotyping for GSTT1

The $25 \mu \mathrm{L}$ volume amplification reaction for GSTT1 gene was done in a duplex PCR assay with a Glyceraldehyde 3-phosphate dehydrogenase (GAPDH) primers used as internal control, for determination of GSTT1 and GSTT1-null genotype. A $5 \mu \mathrm{L}$ DNA template was amplified in a final volume of $25 \mu \mathrm{L}$ amplification reaction of 30 cycles, using the Hot Start Taq 2X Master Mix (M0496L, BioLabs, New England) according to the manufacturer's instructions.

Table 1: The sets of primers used to genotype for IL 4 and IL 13 polymorphisms in the study

\begin{tabular}{|c|c|c|c|}
\hline $\mathbf{S /}$ & Primer Name & Primer Sequence & Reference \\
\hline 1 & IL13 -1055 C/T & $\begin{array}{l}\text { Forward 5'-ATGCCTTGTGAGGAGGGTCAC-3' } \\
\text { Reverse 5'-CCAGTCTCTGCAGGATCAACC- 3' }\end{array}$ & \\
\hline 2 & IL13 -591 A/T & $\begin{array}{l}\text { Forward } \\
\text { CCAGCCTGGCCCAGTTAAGAGTTT-3' }\end{array}$ & \\
\hline 3 & IL13 +130 G/A & $\begin{array}{l}\text { Reverse 5'-CTAATTCCTCCTTGGCCCCACT- } 3^{\prime} \\
\text { Forward 5'- TGGCGTTCTACTCACGTGCT-3' } \\
\text { Reverse 5'-CAGCACAGGCTGAGGTCTAA- 3' }\end{array}$ & Saric et. Al., 2008 \\
\hline 4 & IL4 $-590 \mathrm{C} / \mathrm{T}$ & $\begin{array}{l}\text { Forward } \quad 5^{\prime} \text { - ACTAGGCCTCACCTGATACG-3' } \\
\text { Reverse } \\
5^{\prime} \text { - GTTGTAATGCAGTCCTCCTG-3' }\end{array}$ & Gatlin et. al., 2009 \\
\hline
\end{tabular}




\begin{tabular}{|c|c|c|c|}
\hline 5 & GSTM1 & $\begin{array}{l}\text { G1: 5'-CTGCCCTACTTGATTGATGGG- 3' } \\
\text { G2: 5'-CTGGATTGTAGCAGATCATGC -3' }\end{array}$ & $\begin{array}{l}\text { Brockmoller et. al., } \\
2000\end{array}$ \\
\hline 6 & GSTT1 & $\begin{array}{l}\text { Forward: 5'- TCT GCC GCC CGA AAC CTT- } 3^{\prime} \\
\text { Reverse: 5'- ACG TCC TCT TGT CCC CCA TTC- } \\
3^{\prime}\end{array}$ & Matic et. al., 2016 \\
\hline 7 & GAPDH & $\begin{array}{l}\text { Forward: } 5^{\prime} \text { - CAA AGC TTG TGC CCA GAC } \\
\text { TGT- } 3^{\prime} \\
\text { Reverse: } 5^{\prime} \text { - CGC CCA ATA CGA CCA AAT CT- } \\
3^{\prime}\end{array}$ & 23 \\
\hline
\end{tabular}

\section{Statistical Analysis}

Statistical analysis was done using SPSS version 20.0 to determine the $\mathbf{X}^{2}$ and Odds ratio with $P$ value set at $<0.05$.

\section{Results}

1. Prevalence of urinary schistosomiasis and bladder pathology

A total of 371 participants (130 males and 241 females) aged 30-90 years were recruited for the study. While 369 were eventually screened for S. haematobium infection and 362 for bladder pathologies, some of the volunteers were excluded from the study using the exclusion criteria (Table 2). The mean age of the participants was $48.6 \pm 0.6$ years. The overall prevalence of $S$. haematobium in the sampled population was $29.3 \%$ (108/369), 42 $(11.4 \%)$ in males and $66(17.9 \%)$ in females (Table 2). The Eggua community had the highest prevalence of infection $58(16.0 \%)$, while Ibeku 9 (2.5\%) had the least prevalence of infection (Table 2). Bladder pathologies were observed in $32.3 \%(117 / 362)$ of sampled population (Table 2).

Table 2: Prevalence of Schistosomiasis among the settlements in Eggua

\section{S. haematobium Infection}

\begin{tabular}{ccccccc} 
Villages & $\begin{array}{c}\text { Positive } \\
\text { N (\%) }\end{array}$ & $\begin{array}{c}\text { Negative } \\
\text { N (\%) }\end{array}$ & $\begin{array}{c}\text { Total } \\
\text { N (\%) }\end{array}$ & $\begin{array}{c}\text { Prevalence/ } \\
\text { villages (\%) }\end{array}$ & \multicolumn{2}{c}{ Bladder Pathology } \\
\hline Eggua & $58(16.0)$ & $149(41.2)$ & $207(57.2)$ & 28.0 & Mild & $109(30.1)$ \\
Iganalade & $10(2.8)$ & $27(7.5)$ & $37(10.2)$ & 27.0 & Severe & $8(2.21)$ \\
Agbon-Ojodu & $31(8.6)$ & $56(15.5)$ & $87(24.0)$ & 35.6 & Total & $117(32.3)$ \\
Ibeku & $9(2.5)$ & $18(5.0)$ & $27(7.5)$ & 33.3 & & \\
Tata & $0(0.0)$ & $4(1.1)$ & $4(1.1)$ & 0 & & \\
Total & $108(29.8)$ & $254(70.2)$ & $362(100.0)$ & & & \\
$\begin{array}{c}\text { Infection } \\
\text { Intensity/ } \\
\text { Gender }\end{array}$ & Light & Heavy & Male & Female & & \\
\hline
\end{tabular}

2.

3. Cytokine gene polymorphisms and genetic susceptibility to schistosomiasis None of the $S$. haematobium infection cases was amplified for IL $13+130$ and IL $13-591$ gene polymorphisms while genetic polymorphisms in IL $4-590$ and IL $13-1055$ were found in some of the infected participants. IL $4-590$ and IL $13-1055$ were amplified and found to have 200bp and 230bp, respectively. Majority (4 (40\%) IL131055 and 11 (42.3\%) IL4-590) of the cytokine polymorphisms clustered around Eggua central among the understudied settlements (Table 3). 
Table 3: Distribution of cytokine polymorphisms across settlements in Eggua

\begin{tabular}{|c|c|c|c|c|c|c|}
\hline \multirow[b]{2}{*}{ Villages } & \multicolumn{2}{|c|}{ IL $13-1055$ C/T } & \multirow[b]{2}{*}{$\begin{array}{c}\text { Total } \\
\text { N (\%) }\end{array}$} & \multicolumn{2}{|c|}{ IL $4-590 \mathrm{C} / \mathrm{T}$} & \multirow[b]{2}{*}{$\begin{array}{l}\text { Total } \\
\text { N (\%) }\end{array}$} \\
\hline & $\begin{array}{c}\text { Present } \\
\mathrm{N}(\%)\end{array}$ & $\begin{array}{l}\text { Absent } \\
\mathrm{N}(\%)\end{array}$ & & $\begin{array}{c}\text { Present } \\
\mathrm{N}(\%)\end{array}$ & $\begin{array}{l}\text { Absent } \\
\text { N (\%) }\end{array}$ & \\
\hline $\begin{array}{l}\text { Eggua } \\
\text { Central }\end{array}$ & $4(40.0)$ & $25(25.5)$ & $29(26.9)$ & $11(42.3)$ & $18(22.0)$ & 29 (26.9) \\
\hline Iganalade & $2(20.0)$ & 17 (17.3) & 19 (17.6) & $4(15.4)$ & 15 (18.3) & 19 (17.6) \\
\hline $\begin{array}{l}\text { Agbon } \\
\text { Ojodu }\end{array}$ & $3(30.0)$ & $21(21.4)$ & 2.2) & $3(11.5)$ & $21(25.6)$ & $24(22.2)$ \\
\hline Ibeku & $1(10.0)$ & $18(1$ & $19(1$ & $1(3$. & $18(2$ & 19 (17.6) \\
\hline Tata & $0(0.0)$ & $17(1$ & $17(1$ & 7 (26.9) & $10(1$ & $17(15.7)$ \\
\hline Total & $10(100.0)$ & $98(100.0)$ & $108(100.0)$ & $26(100.0)$ & $82(100.0)$ & $108(100.0)$ \\
\hline
\end{tabular}

Only 10 samples from the infected participants (9.3\%) amplified for IL $13-1055$ polymorphism when analyzed for genetic susceptibility to schistosomiasis, and this showed no risk of infection in males $3(7.5 \%)$ (OR $0.7,95 \% \mathrm{CI}$ $0.3-2.1)$ and slight risk in females $7(10.3 \%)$
(OR 1.1, 95\% CI 0.7-1.7). Among 26 (24.1\%) S. haematobium- infected participants with IL 4-590 polymorphism, a slight risk of infection was found both in male 10 (25\%) (OR 1.05, $95 \%$ CI $0.5-01.8)$ and female $16(23.5 \%)$ (OR $1.05 ; 95 \%$ CI 0.5-01.8) participants (Table 4).

Table 4: Cytokines as susceptibility risk factors for schistosomiasis after stratification by gender

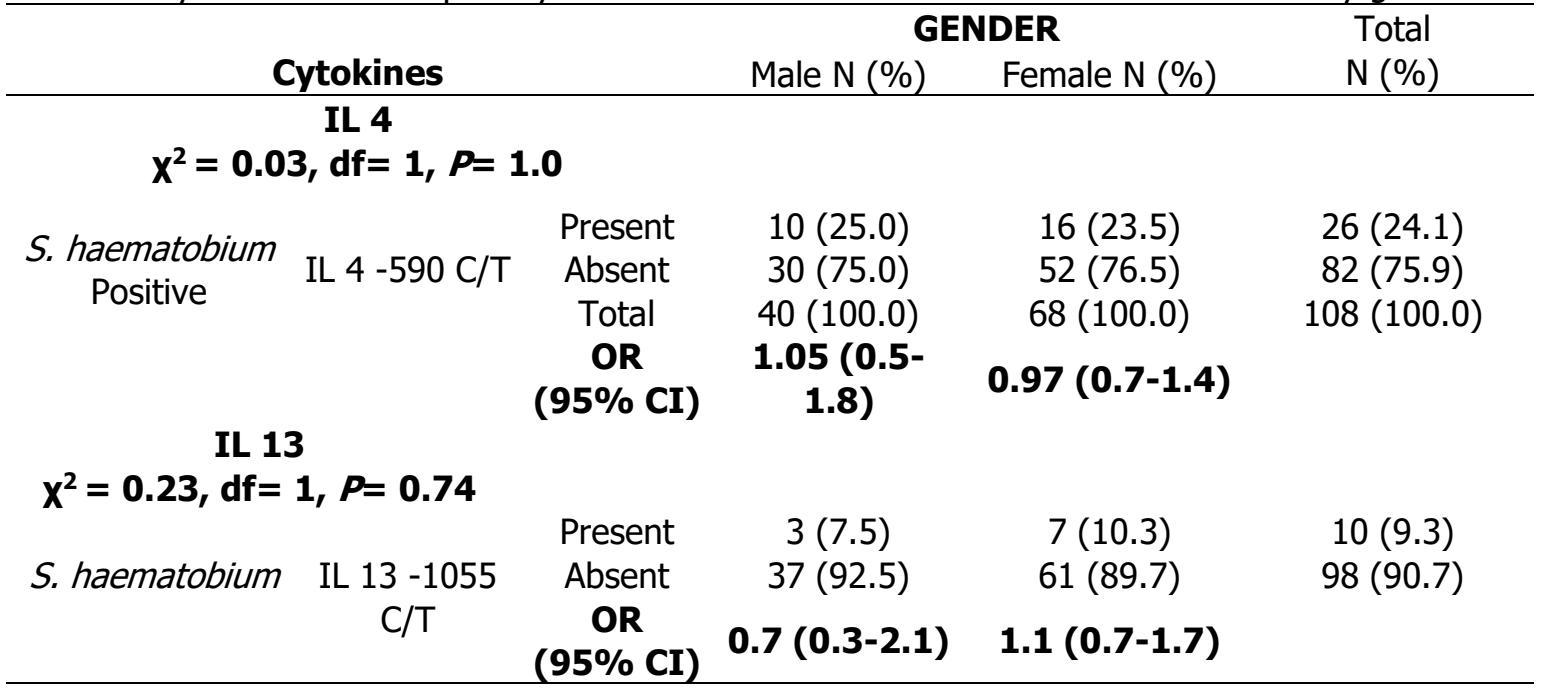

4. $\quad$ GST gene polymorphisms in susceptibility to schistosomiasis- associated bladder pathologies

Amplification of GSTM1 and GSTT1 genes yielded 500bp and 400bp fragments, respectively, among the sampled population. The GSTMI amplicons were found in 36 (30.8\%) pathology cases and 7 (7.1\%) control samples while GSTT1 was found in $20(17.1 \%)$ pathology cases and $4(4.1 \%)$ control samples.
Most of the participants with bladder pathologies had GSTM1 81 (69.2\%) and GSTT1 97 (82.9) null genotypes, respectively. These revealed an elevated risk of bladder pathologies for participants carrying either the GSTM1 (OR= 4.3, 95\% CI 2.0-9.2) or GSTT1 (OR= 4.2, $95 \%$ CI 1.5-12) polymorphic null genotype when compared to those with the corresponding genotype. However there were wide confidence intervals (Table 5).

Table 5: Association between GSTT1 and GSTM1 polymorphisms and bladder pathology risk among the participants 


\begin{tabular}{|c|c|c|c|c|c|c|c|c|}
\hline \multirow{2}{*}{ Genotype } & \multicolumn{4}{|c|}{ Pathology } & \multicolumn{4}{|c|}{ Pathology Intensity } \\
\hline & $\begin{array}{l}\text { Cases } \\
\text { N (\%) }\end{array}$ & $\begin{array}{c}\text { Control } \\
\text { N }(\%)\end{array}$ & $\begin{array}{c}\text { OR }^{b} \\
95 \% \mathbf{C I}^{\mathrm{a}}\end{array}$ & $\begin{array}{c}\boldsymbol{P} \\
2 \\
\text { tailed }\end{array}$ & $\begin{array}{c}\text { Mild } \\
\text { N (\%) }\end{array}$ & $\begin{array}{l}\text { Severe } \\
\text { N (\%) }\end{array}$ & $\begin{array}{c}\text { OR } \\
95 \% \mathrm{CI}^{\mathrm{b}}\end{array}$ & $\begin{array}{c}\boldsymbol{P} \\
\mathbf{2} \\
\text { tailed }\end{array}$ \\
\hline \multicolumn{9}{|l|}{ GSTM1 } \\
\hline Active & $36(30.8)$ & $7(7.1)$ & 1.00ref & 0.001 & $34(30.2)$ & $2(30.0)$ & 1.00ref & 1.00 \\
\hline Null & $81(69.2)$ & 91 (92.9) & $4.3(2.0-9.2)$ & & $74(69.8)$ & $6(70.0)$ & $1.0(0.4-2.7)$ & \\
\hline \multicolumn{9}{|l|}{ GSTT1 } \\
\hline Active & $20(17.1)$ & $4(4.1)$ & 1.00ref & 0.002 & $18(16.5)$ & $2(20.0)$ & 1.00ref & 0.63 \\
\hline Null & 97 (82.9) & 94 (95.9) & $4.2(1.5-12)$ & & $91(83.5)$ & $6(80.0)$ & $0.8(0.2-3.1)$ & \\
\hline \multicolumn{9}{|c|}{ Combined Genotype } \\
\hline Both Active & $7(6.0)$ & $0(0)$ & 1.00ref & 0.1 & $7(6.6)$ & $0(0)$ & 1.00ref & 0.49 \\
\hline Either & $42(35.9)$ & $11(11.2)$ & $3.4(1.9-6.2)$ & & $36(34.0)$ & $4(50.0)$ & $0.7(0.4-1.4)$ & \\
\hline \multicolumn{9}{|l|}{ Active } \\
\hline Both Null & $68(58.1)$ & $87(88.8)$ & $0.6(0.6-0.8)$ & & $63(59.4)$ & $4(50.0)$ & $1.2(0.7-2.4)$ & \\
\hline
\end{tabular}

aConfidence Interval, bodds ratio, ref-Reference

The risks associated with combined activities of the GSTM1 and GSTT1 genes were also examined and a higher risk of having bladder pathology was found in participants with one of either of the active genes (OR=3.4, 95\% CI 1.9-6.2) compared to those having both null genotypes (OR $=0.6,95 \%$ CI $0.6-0.8)$. There was no distinctive risk found in having a high intensity of pathology with any of the GST genotypes when the combined variant and active genotype were considered, but there was a slight risk of mild bladder pathology in the participants in the presence of both inactive variants (both null genotype) when compared to those with either one alone $(\mathrm{OR}=1.2,95 \%$ CI 0.7-2.4).

Association of schistosomiasis and smoking in the development of bladder pathology among the participants was examined within the genotypes. It showed that the $S$. haematobium - infected participants had more variant GSTM1 $73.1 \%(\mathrm{OR}=1.7,95 \%$ CI 1.0 3) and GSTT1 $85.9 \%(\mathrm{OR}=1.5,95 \%$ CI $0.7-$ 3.1) null polymorphisms, revealing a slight risk of bladder pathology (Table 6). The case was different among smokers with null genotype for the GSTM1 and GSTT1 genotypes with higher risk of bladder pathology ( $\mathrm{OR}=3,95 \% \mathrm{CI} 1-7$, $P=0.05 ; \mathrm{OR}=4,95 \%$ CI $1-11, P=0.006$ respectively).

There was a slight risk of bladder pathology among the smokers and $S$. haematobiuminfected participants with GSTT1 and GSTM1 null polymorphisms (Supplementary Table 1).

Supplementary Table 1: Relative risk estimates of bladder pathology associated with smoking and $S$. haematobium infection after stratification by genotype

\begin{tabular}{|c|c|c|c|c|c|}
\hline \multirow[b]{2}{*}{ Risk Factors } & \multirow{2}{*}{$\begin{array}{c}\text { GSTS } \\
\text { Genotype }\end{array}$} & \multicolumn{2}{|c|}{ Pathology Status } & \multirow[b]{2}{*}{$\begin{array}{c}\text { bOR (95\% } \\
\left.{ }^{\text {a }} \mathrm{CI}\right)\end{array}$} & \multirow[b]{2}{*}{$\begin{array}{c}\text { P value } \\
(2 \\
\text { Tailed })\end{array}$} \\
\hline & & $\begin{array}{c}\text { Cases N } \\
(\%)\end{array}$ & $\begin{array}{c}\text { Control N } \\
(\%)\end{array}$ & & \\
\hline \multicolumn{6}{|c|}{$\begin{array}{l}\text { Cigarette Smoking } \\
\text { GSTT1 }\end{array}$} \\
\hline Smokers & $\begin{array}{l}\text { Active } \\
\text { Null }\end{array}$ & $\begin{array}{l}6(40.0) \\
9(60.0)\end{array}$ & $\begin{array}{c}0(0) \\
2(100)\end{array}$ & $\begin{array}{c}\text { 1.0ref } \\
1.2(0.9-1.6)\end{array}$ & 0.4 \\
\hline Non Smokers & $\begin{array}{l}\text { Active } \\
\text { Null }\end{array}$ & $\begin{array}{l}14(13.7) \\
88(86.3)\end{array}$ & $\begin{array}{c}4(4.2) \\
92(95.8)\end{array}$ & $\begin{array}{c}\text { 1.0ref } \\
1.6(1.1-2.1)\end{array}$ & 0.02 \\
\hline $\begin{array}{l}\text { GSTM1 } \\
\text { Smokers } \\
\end{array}$ & Active & $7(46.7)$ & $0(0.0)$ & 1.0ref & 0.48 \\
\hline
\end{tabular}




\begin{tabular}{lccccc}
\hline \multirow{3}{*}{ Non-smokers } & Null & $8(53.3)$ & $2(100)$ & $1.3(0.9-1.7)$ & \\
& Active & $29(28.4)$ & $7(7.3)$ & 1.0 ref & 0.001 \\
& Null & $73(71.6)$ & $89(92.7)$ & 1.8 &
\end{tabular}

\section{S. haematobium Infection}

\section{GSTT1 \\ Positive}

Negative

GSTM1

Positive

Active
Null
Active
Null

Active

Null

Active

Null

$\begin{array}{lc}10(16.4) & 1(5.9) \\ 51(83.6) & 16(94.1) \\ 10(18.2) & 3(3.7) \\ 45(81.8) & 78(96.3)\end{array}$

$20(32.8)$

$41(67.2)$

$15(27.3)$

$40(72.7)$
$1(5.9)$

$16(94.1)$

$6(7.4)$

$75(92.6)$

$\begin{array}{cc}\begin{array}{c}1.0 \text { ref } \\ 1.2(0.9-1.5) \\ 1.0 \text { ref }\end{array} & 0.43 \\ 2.1(1.4-3.1) & 0.007 \\ & \\ \begin{array}{c}1.0 \text { ref } \\ 7.8(0.9-63.1) \\ \text { 1.0ref }\end{array} & 0.02 \\ 4.6(1.7-13.0) & 0.002 \\ \end{array}$

aConfidence Interval, bodds ratio, ref- Reference

These risks were significant among nonsmokers with GSTT1 (OR=1.6, 95\% CI 1.1-2.1, $P=0.02)$ and GSTM1 (OR=1.8, 95\% CI 1.42.2, $P=0.001$ ) null genotypes in the population studied. Participants with or without $S$. haematobium infection having the null GSTT1 and GSTM1 genotype also had a relatively small elevation in risk while some differences in the magnitude of risk associated with $S$. haematobium infection were apparent between the variants of the GSTM1 genotype (OR 7.8, $95 \%$ CI $0.9-63.1, P=0.02)$. Using multivariate analysis, it is evident in this study that bladder pathology has a statistically significant association with Schistosoma infection ( $F$ $(1,205)=33.04 ; p=0.001$; partial $\left.\eta^{2}=0.14\right)$, GSTM1 polymorphisms $(F(1,205)=13.32$; $\mathrm{p}=0.001$; partial $\left.\eta^{2}=0.06\right)$ and cigarette smoking $(F(1,205)=5.79 ; p=0.01$; partial $\left.\eta^{2}=0.03\right)$. there was also statistically significant difference in bladder pathology and the studied risk factors $(F(5,201)=11.42 ; p=0.001 ;$ Wilk's $A=0.779$, partial $\eta^{2}=0.06$ ) (Supplementary Table 2).

Supplementary Table 2: Multivariate analysis showing the relationship between bladder pathology and gene polymorphisms among the participants

\begin{tabular}{|c|c|c|c|c|c|c|c|c|}
\hline Source & Risk Factors & $\begin{array}{l}\text { Type III } \\
\text { Sum of } \\
\text { Squares }\end{array}$ & Df & $\begin{array}{l}\text { Mean } \\
\text { Square }\end{array}$ & $\mathbf{F}$ & Sig. & $\begin{array}{l}\text { Partial Eta } \\
\text { Squared }\end{array}$ & $\begin{array}{l}\text { Noncent. } \\
\text { Parameter }\end{array}$ \\
\hline \multirow{6}{*}{$\begin{array}{l}\text { Bladder } \\
\text { Pathology }\end{array}$} & Schistosoma Infection & 6.637 & 1 & 6.637 & 33.035 & 0.000 & 0.139 & 33.035 \\
\hline & GSTM1 polymorphisms & 1.775 & 1 & 1.775 & 13.324 & 0.000 & 0.061 & 13.324 \\
\hline & GSTT polymorphisms & 0.318 & 1 & 0.318 & 4.259 & 0.040 & 0.020 & 4.259 \\
\hline & $\begin{array}{c}\text { Combine Genotype for } \\
\text { GSTs }\end{array}$ & 3.594 & 1 & 3.594 & 20.846 & 0.000 & 0.092 & 20.846 \\
\hline & Cigarette Smoking & 0.334 & 1 & 0.334 & 5.787 & 0.017 & 0.027 & 5.787 \\
\hline & Effect & Value & $\mathbf{F}$ & $\begin{array}{c}\text { Hypothesis } \\
\text { df }\end{array}$ & Error df & Sig. & $\begin{array}{l}\text { Partial Eta } \\
\text { Squared }\end{array}$ & $\begin{array}{l}\text { Noncent. } \\
\text { Parameter }\end{array}$ \\
\hline $\begin{array}{l}\text { Bladder } \\
\text { Pathology }\end{array}$ & Wilks' Lambda & 0.779 & $11.419^{b}$ & 5.000 & 201.000 & 0.000 & 0.221 & 57.094 \\
\hline
\end{tabular}

3. 


\section{DISCUSSION}

\section{1. \\ Infection and Pathology}

The overall prevalence $(29.3 \%)$ in this study was higher than several reported cases in Nigeria (Nmorsi et. al., 2007; Dawet et. al., 2012; Ugochukwu et. al., 2013; Olayinka et. al., 2020). This could further explain the continuous and long-time exposure to infection and possibly contribute to $S$. haematobium subtle morbidity.

The consistently higher frequency of light intensity of $S$. haematobium infection observed in this study as previously seen in Onile et. al., (2016) could be explained by some possible level of gradual development of acquired protected immunity by adults in this community due to chronic exposure to schistosomiasis (Barbosa et. al., 2006). Also, according to the WHO Expert Committee (WHO, 2002), prevalence and intensity of infection have been directly related to the patterns of variation with age with a reported decline in adults, an assertion supported by studies in Nigerian populations (Pukuma and Musa, 2007; Dawaki et. al., 2016). Pearce and MacDonald, (2002) also reported an obvious pattern of agedependent intensity of infection where those who are below the age of puberty carry the most parasites, and those in older age groups are generally less heavily infected.

The association between $S$. haematobium infection and the presence of urinary tract abnormalities was consistent in our studies and similar to other previous reports (Nmorsi et. al., 2007; Ekwunife et. al., 2009; Onile et. al., 2016; Serieye et. al., 1996). Also, S. haematobium infection has been associated with a two to tenfold increase in the risk of bladder squamous cell carcinoma, as well as being a potential cause of kidney damage (Driguez et. al., 2016). In fact, in some of the regions where $S$. haematobium is endemic, bladder cancer has been marked as the most common cancer in men and the second in women, just behind breast cancer, and accounts for as much as $30 \%$ of all cancer cases (Botelho et. al., 2010). A meta-analysis of the estimated disease burden showed that morbidity and mortality attributed to schistosomiasis increases with
DALYs (disability-adjusted life years) which had risen to about 20\% increase in the past 20 years (Driguez et. al., 2016; Murray et. al., 2013). A retrospective review of clinical records of bladder cancer cases in Sokoto, Nigeria between 1999 and 2004 showed a 4.7 fold rise in the number of bladder cancer cases, with squamous cell carcinoma composed of $65.1 \%$ of histologically verified cases and $50 \%$ of the squamous cell carcinoma showed evidence of chronic urinary schistosomiasis (Mungadi and Malami, 2007).

\section{Genetic Susceptibility to Schistosomiasis}

The presence of polymorphisms in cytokine genes IL 4-590 C/T and IL13-1055 C/T among the $S$. haematobium- infected participants in this study was similar to findings from some previous studies (Kouriba et. al., 2005; Gatlin et. al., 2009; He et. al., 2008). Gatlin et. al., (2009) had reported more resistance to infection among men with a combination of IL-13 $21055 \mathrm{C} / \mathrm{T}$ and IL-4 $2590 \mathrm{C} / \mathrm{T}$ genotypes when compared to those seen with the sum of the separate effects of $I L-1321055 \mathrm{C} / \mathrm{T}$ and $I L-42590 \mathrm{C} / \mathrm{T}$ on resistance. Other studies have shown a marked increase in the plasma levels of IL-5 and IL-13 in individuals identified as being resistant to schistosome infection (Leenstra et. al., 2006). Therefore, to understand the role of this heterozygous cytokine as a susceptibility or resistance factor, further post- treatment follow-up study will be required among the infected participants to establish the role of these cytokines as has been done in other similar studies (Cameron et. al., 2006; Gatlin et. al., 2009). Gatlin et. al., (2009) had reported that individuals with polymorphisms at positions $I L-13-1055$ and IL$4-590$ are more likely to require fewer reinfections and treatments to become resistant to reinfection than individuals who are homozygous at either position. Another study in Mali revealed an association between a singlenucleotide polymorphism in the STAT6 gene at $12 q 13.3$ and intensity of infection by $S$. haematobium; this polymorphism had an additive effect with $/ L 13-1055$ (He et. al., 2008).

Other analyses of $S$. haematobium infection in Mali revealed that in chromosomal region 5q31q33, polymorphisms in the $I L 13$ gene promoter 
at position -1055 and -591 were associated with the infection rate: alleles $-1055 \mathrm{C}$ and $-591 \mathrm{~A}$ were preferentially transmitted to children with $10 \%$ highest infection rate, whereas $-1055 T$ associated with the lowest infection levels (Kouriba et. al., 2005). IL4 $-590 T$ allele has been associated with high IgE production, thereby having increased resistance to infection (Russell et. al., 2015).

Evidence has shown that imbalance in activation and detoxification by detoxifying enzymes (GSTs) due to gene polymorphisms may influence an increase in bladder cancer risk due to accumulation of carcinogen metabolites (McGrath et. al., 2006; Ying et. al., 2016; Jobaida et. al., 2016; Yajie et. al., 2016). Common polymorphisms occur in almost all members of GSTs (Ying et. al., 2016) and several types of allelic variations have been observed (Djukic et. al., 2013; Yajie et. al., 2016; Matic et. al., 2016) which include GSTM1 and GSTT1 class deletion polymorphism (GSTM1-null and GSTT1-null). The null genotypes produce no GSTM1 and GSTT1 protein and consequently completely lack GSTM1 and GSTT1 enzymatic activity (Djukic et. al., 2013).

In this study, GSTM1 and GSTT1 null polymorphisms were shown to significantly increase the risk of structural bladder pathology. This agrees with Arnaldo et. al., (2000), Aktas et. al., (2001), Cengiz et. al., (2007), Yajie et. al., (2016) and Jobaida et. al., (2016) who also observed a risk of bladder cancer with GSTM1 and GSTT1 null polymorphisms. Okkels et. al., (1996) and Arnaldo et. al., (2000) reported that the association of GSTM1 null genotype with bladder tumour was more apparent in a group with less aggressive tumours, as we also observed in this study. This could further support the presence of GSTM1 null genotype among the urinary tract pathology cases (an indicator of early stage of possible progression to bladder cancer). Among the bladder pathology cases, the distribution of the polymorphisms was relatively similar to the control group with slightly higher GSTM1 null genotype in the control cases. This is similar but considerably higher than what was reported in several other studies (Okkels et. al., 1996;
Arnaldo et. al.,2000; Jobaida et. al., 2016). The role of GSTT1 null genotype in bladder cancer risk remains unresolved. Several studies suggested an increased risk (Moore et. al., 2004; Yajie et. al., 2016; Jobaida et. al., 2016; Ying et. al., 2016), but others suggested no risks or low risks (Karagas et. al., 2005; McGrath et. al., 2006; Matic et. al., 2016). In the present study, an elevated risk of bladder cancer was found among the $S$. haematobium - infected participants; and this was more in smokers with null GSTM1 and GSTT1 polymorphisms. This finding is similar to those observed by Moore et. al., (2004) and Yu et. al., (2017) where elevated risk to bladder cancer was only seen in smokers with the GSTT1 null polymorphism and seems to buttress the observation that smoking is the most important risk factor for susceptibility to bladder cancer.

\section{$2 . \quad$ Conclusion}

The prevalence of urinary schistosomiasis among adults is relatively high in the study area when compared with other areas in Nigeria. Individuals with bladder pathologies could have heavy or light intensity of schistosomiasis or have no existing infection at all. However, long term exposure to schistosomiasis is necessary for the development of bladder pathology which may eventually advance to cancer. IL 13-1055 polymorphisms did not indicate susceptibility to schistosomiasis in males, but a slight risk was found in females. GSTM1 and GSTT1 polymorphisms were associated with elevated risk of bladder pathology with the pathology and schistosomiasis group having more GST polymorphisms than the group with only bladder pathology.

Limitation of the study

In order to elucidate properly the role of GST (GSTM1 and GSTT1) polymorphisms in susceptibility to urinary schistosomiasis associated bladder pathology, it is important to conduct a repeat of this study with a much larger sample size. Also, molecularly characterized schistosomiasis negative control samples will be required to further establishe the relationship (susceptibility/resistance) between the cytokines (IL-13 -1055 and IL-4 590 ) and urinary schistosomiasis.

\section{Acknowledgements.}

The authors thank Kabiyesi Oniggua, Alhaji Idowu, the Baales and all the people who 
participated in the study. The CIA thanks Nuria Malats for discussions.

\section{Funding}

The CIA acknowledges The World Academy of Science associate fellowship. The funders had no role in study design, data collection and analysis, decision to publish, or preparation of the manuscript.

\section{Disclosure of Conflict of interest}

The authors declare that they have no conflicts of interest.

\section{References}

Abdulkadir, A. A., Ahmed, M., Abubakar B.M., Suleiman, I.E., Yusuf I., Imam, I.M., Sule, A.A., Tela, U.M., Dogo, H.M., Yakasai A.M., Musa, B.M. (2017). Prevalence of urinary schistosomiasis in Nigeria, 1994-2015: Systematic review and meta-analysis. Afr $\mathrm{J}$. Urol. 23.3: 228-239.

Adebayo, A. S., Survayanshi M., Bhute S., Agunloye, A. M., Isokpehi, R. D., et. al. (2017). Correction: The microbiome in urogenital schistosomiasis and induced bladder pathologies. PLOS Neg. Trop. Dis. 11(11): e0006067

Adenowo, A. F., Oyinloye, B. E., Ogunyinka, B. I., and Kappo, A. P. (2015). Impact of human schistosomiasis in sub-Saharan Africa. Brazilian J. Infect. Dis. 1 9.2: 196-205.

Aktas, D., Ozen, H., Atsu, N., Tekin, A., Sozen, S. and Tuncbilek, E. (2001). Glutathione S transferase M1 gene polymorphism in bladder cancer patients. Cancer Gen. and Cytogen. 125: $1-4$.

Anumudu, C. I., Onile, O. S., Awobode, H., Gboyega-Tokunbo, A., Oladele, V., Adebayo, A., Chouvwen, C. O. (2019). Socio-cultural and environmental determinants of a proposed schistosomiasis health education intervention in Eggua, Nigeria. J. Behav. Health. 8, 3, 92-100, DOI 10.5455/jbh.20190521094753

Arnaldo, J. C. F., Henriqueta, B. C., Fernando, T. S., Jorge, M., Alexandre, J. L., Fernando, J. R. (2000). Genetic polymorphisms of genes gstm1 and cyp2d6 and Bladder cancer. Braz. J. Urol. 26.3: 250-255.
Barbosa, I., Caldeira, R. I., Carvalho, O. S., Vidigal, T. H. D.A., Jannott-Passos, L. K., Coelho, P. M. (2006). Resistance to S. mansoni by transplantation of APO Biomphalaria tenagophilia. Parasite Immunol. 28: 209-212.

Botelho, M. C., Machado, J. C., de Costa, J. M. (2010). Schistosoma hematobium and bladder cancer- What lies Beneath? Virulence. 1.2: 847.

Brockmoller, J., Cascorbi, I., Henning, S., Meisel, C. and Roots, I. (2000). Molecular genetics of cancer susceptibility. Pharmacology. 61: 212-27.

Cameron, L., Webster, R. B., Strempel, J. M., Kiesler, P., Kabesch, M., Ramachandran, H., Yu, L., Stern, D. A., Graves, P. E., Lohman, I. C., Wright, A. L., Halonen, M, Klimecki, W. T. and Vercelli, D. (2006). Th2 cell-selective enhancement of human IL13 transcription by IL13-1112C > T, a polymorphism associated with allergic inflammation. J. Immunol. 177: 8633-8642.

Cengis, M., Ozaydin, A., Ozkilic, A. C., Dedekarginoglu, G. (2007). The investigation of GSTT1, GSTM1 and SOD polymorphism in bladder cancer patients. Int'l Urol and Neph. DOI 10.1007/s11255-007-9179-9.

Dawaki, S., Al-Mekhlafi, H. M., Ithoi, I., Ibrahim, J., Abdulsalam, A. M., Ahmed, A., Sady, H., Atroosh, W. M., Al-Areeqi, M. A., Elyana, F. N., Nasr, N. A., Surin, J. (2016). Prevalence and risk factors of schistosomiasis among Hausa communities in Kano State, Nigeria. Revista do Inst. de Med. Trop. de Sao Paulo. 58, 54.

Dawet, A., Benjamin, C. B. and Yakubu, D. B. (2012). Prevalence and intensity of $S$. haematobium among residents of Gwong and Kabong in Jos North Local Government Area, Plateau State, Nigeria. Int'I J. Trop. Med. 7.2: 69-73.

Dessein, A. J., Chevillard, C., Marquet, S., Henri, S., Hillaire, D. and Dessein, H. (2001). Genetics of parasitic infections. Drug Metabolism Dispos. 29: 484-488.

Djukic, T. I., Savic-Radojevic, A. R., Pekmezovic, T. D., Matic, M. G., PljesaErcegovac, M. S., Coric, V. M., Radic, T. M., 
Suvakov, S. R., Krivic, B. N., Dragicevicm D. P., Simic, T. P. (2013). Glutathione S-Transferase T1, 01 and 02 Polymorphisms Are Associated with Survival in Muscle Invasive Bladder Cancer Patients. PLOS ONE. 8.9: e74724. doi:10.1371/journal.pone.0074724.

Driguez, P., McManus, D. P. and Gobert, G. N. (2016). Clinical implications of recent findings in schistosome proteomics. Expert Rev. Prot. 13.1: 19-33.

Ekwunife, C. A., Okafor, F. C. and Nwaorgu, O. C. (2009). Ultrasonographic screening of urinary schistosomiasis infected patients in Agulu community, Anambra state, southeast Nigeria. Int'l Arc. Med. 2: 34.

European Association of Urology (2016). EAU Guidelines on muscle-invasive and mestastic bladder cancer.

Gatlin, M. R., Black, C. L., Mwinzi, P. N., Secor, W. E. and Karanja, D. M. (2009). Association of the Gene Polymorphisms IFN-c +874, IL-13 21055 and IL-4 2590 with Patterns of Reinfection with Schistosoma mansoni. PLoS Neg. Trop. Dis. 3.2: e375.

He, H., Isnard, A., Kouriba, B., Cabantous, S., Dessein, A. (2008). A STAT6 gene polymorphism is associated with high infection levels in urinary schistosomiasis. Genes Immunity. 9: 195-206.

Jobaida, A., Akio, E., Tsutomu, N., Laila, N. I., Fumiaki, S., Hosen, M. I., Mahmud, H., Nabi, A. H. M. (2016). Analyses of Genetic Variations of Glutathione S-Transferase Mu1 and Theta1 Genes in Bangladeshi Tannery Workers and Healthy Controls. BioMed. Research Int'l. 6973057, 8

Karagas, M. R., Park, S., Warren, A., Hamilton, J., Nelson, H. H., Mott, L. A., Kelsey, K. T. (2005). Gender, smoking, glutathione-Stransferase variants and bladder cancer incidence: a population-based study. Cancer Letter. 219.1: 63-69.

Kouriba, B., Chevillard, C., Bream, J. H., Argiro, L., Dessein, H., Arnaud, V., Sangare, L., Dabo, A., Beavogui, A. H., Arama, C., (2005). Analysis of the 5q31-q33 locus shows an association between IL13-1055C/T IL-13-591A/G polymorphisms and Schistosoma haematobium infections. J. Immunol. 174: 6274-6281.

Leenstra. T., Acosta, L. P., Wu, H. W., Langdon, G. C., Solomon, J. S., Manalo, D. L., Su, L., Jiz, M., Jarilla, B., Pablo, A. O. (2006). T-helper-2 cytokine responses to $\mathrm{Sj} 97$ predict resistance to reinfection with Schistosoma japonicum. Infect. Immunol. 74: 370-381.

Matic, M., Dragicevic, B., Pekmezovic, T., Suvakov, S., Savic-Radojevic, A., PljesaErcegovac, M., Dragicevic, D., Smiljic, J. and Simic, T. (2016). Common Polymorphisms in GSTA1, GSTM1 and GSTT1 are Associated with Susceptibility to Urinary Bladder Cancer in Individuals from Balkan Endemic Nephropathy Areas of Serbia. Tohoku J. Exp. Med. 240, 2530

Mbanefo, E. C., Huy, N. T., Wadagni, A. A., Eneanya, C. I., Nwaorgu, O., Hirayama, K. (2014). Host Determinants of Reinfection with Schistosomes in Humans: A Systematic Review and Meta-analysis. PLoS Negl Trop Dis. 8(9): e3164.

McGrath, M., Michaud, D., and De Vivo, I. (2006). Polymorphisms in GSTT1, GSTM1, NAT1 and NAT2 genes and bladder cancer risk in men and women. BMC Cancer. 6:239

Moore, L. E., Wiencke, J. K., Bates, M. N., Zheng, S., Rey, O. A., Smith, A. H. (2004). Investigation off genetic polymorphisms and smoking in a bladder cancer case-control study in Argentina. Cancer Letters. 211: 199-207.

Mungadi, I. A. and Malami, S. A. (2007). Urinary bladder cancer and schistosomiasis in NorthWestern Nigeria. West Afr. J. Med. 26 (3): 2269

Murray, C. J., Vos, T., Lozano, R., Naghavi, M., (2013). Disability-adjusted life years (DALYs) for 291 diseases and injuries in 21 regions, 1990-2010: a systemic analysis for the Global Burden of Disease Study. Lancet. 380: 21972223.

Nmorsi, O. P. G., Ukwandu, N. C. D., Ogoinja, S., Blackie, H. O. T. and Odike, M. A. C. (2007). Urinary tract pathology in some Schistosoma haematobium infected Nigerians. Afri. J. Biotech. 6.2: 123-127.

Okkels, H., Sigsgaard, T., Wolf, H., Autrup, H. (1996). Gluthatione S-transferase $m$ as a risk factor in bladder tumours. Pharmacogenetics. 6: 251-256.

Olayinka, P., Ajide, P., Awobode, H. O., Osundiran, A. J., Onile, O. S., Adebayo, A. S., 
Isokpehi, R. and Anumudu, C. I. (2020). Coinfection of schistosomiasis, malaria, HBV and HIV among adults living in Eggua Community, Ogun State, Nigeria. Nig. J. Parasitol. 41[1]. http://dx.doi.org/10.4314/njpar.v41i1.13.

Onile, O. S., Awobode, H. O., Oladele, V. S., Agunloye, A. M., and Anumudu, C. I. (2016). Detection of urinary tract pathology in some Schistosoma haematobium infected Nigerian Adults. J. Trop. Med. Article ID 5405207. http://dx.doi.org/10.1155/2016/5405207

Onile, O. S., Calder, B., Soares, N. C., Anumudu, C. I., Blackburn, J. M. (2017). Quantitative label-free proteomic analysis of human urine to identify novel candidate protein biomarkers for schistosomiasis. PLoS Negl. Trop. Dis. 11(11): e0006045.

Pearce, E. J. and MacDonald, A. S. (2002). The immunobiology of Schistosomiasis. Nature Reviews immunology, 2: 499-511. doi: $10.1038 / \mathrm{nri} 843$

Pukuma, M. S. and Musa, S. P. (2007). Prevalence of urinary schistosomiasis among residents of Waduku in Lamurde Local Government Area of Adamawa State, Nigeria. Nig. J. Parasitol. 28.2: 65-68

Russell, S. B., Smith, J. C., Huang, M., Trupin, J. S., Williams, S. M. (2015). Pleiotropic Effects of Immune Responses Explain Variation in the Prevalence of Fibroproliferative Diseases. PLoS Genetics. 11.11: e1005568.

Sanyal, S., Fabiola, F., Shigeru, S., Zhengzhong, Z., Gunnar, S., Ulf. N., Hans, W., Per, L., Rajiv, K. and Kari, H. (2003). Polymorphisms in DNA Repair and Metabolic Genes in Bladder Cancer. Carcinogenesis. 1-13.

Saric, J., Jia, V. L., Yulan, W., Keiser, J., Jake, G., Bundy, E. H. and Utzinger, J. (2008). Metabolic Profiling of an Echinostoma caproni Infection in the Mouse for Biomarker Discovery. PLoS Neg. Trop. Dis. 2.7: e254.

Serieye, J., Boisieg, P., Ravaoalimalala, V. E., Ramarokotol, C. E., Leutsches, E. P. and Roux, J. (1996). Schistosoma haematobium infection in western Madagascar: morbidity determined by ultrasonography. Trans. Royal Soc. Trop. Med. and Hyg. 90,398-401.
Sheweita, S. A., El-Shahat, F. G., Bazeed, M. A., Abu, El-Maati, M. R., and O'Connor, P. J. (2004). Effects of Schistosoma haematobium infection on drug-metabolizing enzymes in human bladder cancer tissues. Cancer Letter 205: 15-21.

Somail, S., Fabiola, F., Shigeru, S., Zhengzhong, Z., Gunnar, S., Ulf. N., Hans, W., Larsson, P., Rajiv, K. and Kari, H. (2003). Polymorphisms in DNA Repair and Metabolic Genes in Bladder Cancer. Carcinogenesis. 1-13.

Ugochukwu, D. O., Onwuliri, C. O. E., Osuala, F. O. U., Dozie, I. N. S., Opara, F. N. and Nwenyi, U. C. (2013). Endemicity of schistosomiasis in some parts of Anambra State, Nigeria. J. Med. Lab. Diagnosis. 4.5: 5461.

W.H.O. (2018). Key fact sheet on schistosomiasis. http://www.who.int/newsroom/fact-sheets/detail/schistosomiasis.

W.H.O. Expert Committee (2002). Prevention and control of schistosomiasis and soiltransmitted helminthiasis. World Health Organ Tech Rep Ser, 912: 1-57.

Wilson, M. S., Mentink-Kane, M. M., Pesce, J. T., Ramalingam, T. R., Thompson, R., and Wynn, T. A. (2007). Immunopathology of schistosomiasis. Immunol. and Cell Bio. 85. 2: 148-154.

Yajie, Y., Xiao, L., Chao, L., Jingyuan, T., Zhiqiang, Q., Chengming, W., Weizhang, X., Yibo, H., Pengfei, S. and Ting, X. (2016). The relationship between GSTA1, GSTM1, GSTP1, and GSTT1 genetic polymorphisms and bladder cancer susceptibility A meta-analysis. Medicine. 95: 37(e4900).

Yassir, S., Randa, E. E., Theerakamol, P., Azzam, A., Mohamed, A. Z. and Mudather A. K. (2017). Schistosomiasis as a disease and its prevalence in Sudan: An overview. J. Coastal Life Med. 5.3: 129-133.

Ying W., Jing, H., Tian-Jiao, M., Wei, L., Feng, L., Han, S. and Zhen-Ya, S. (2016). GSTT1Null Genotype Significantly Increases the Susceptibility to Urinary System Cancer: Evidences from 63,876 Subjects. J. Cancer 7.12: $1680-1693$. 
Yu, C., Hequn, C., Longfei, L., Long, W., Zhi, C., Feng, Z., Jinbo, C., Chao L., and Xiongbing, Z. (2017). GSTM1 and GSTT1 polymorphisms are associated with increased bladder cancer risk: Evidence from updated metaanalysis. Oncotarget. 8(2), 3246-3258.

Zaghloul, M. S. (2012). Bladder cancer by schistosomiasis. J. Egypt. Nat. Cancer Inst. 24: 151-159 